\title{
Prototype Aplikasi Sistem Rekam Medis Pasien Berbasis Web pada Klinik Karawaci Medika
}

\author{
Muhaimin Hasanudin ${ }^{* 1}$, Eduard Hotman Purba ${ }^{2}$, Anggi Prabowo ${ }^{3}$ \\ ${ }^{1,2,3}$ Program Studi Teknik Informatika STMIK Raharja \\ E-mail: ${ }^{\text {11 muhaimin.hasanudin@ } \text { raharja.info, }}{ }^{2}$ eduard@ raharja.info, \\ anggi.prabowo@ raharja.info
}

\begin{abstract}
Abstrak
Penerapan Teknologi dalam bidang kesehatan saat ini dapat mempermudah segala pekerjaan khususnya pendaftaran dan pengolahan data yang membutuhkan kecepatan, ketepatan dan kevalidan data. Prototype aplikasi rekam medis pasien berbasis web bertujuan untuk melakukan pemenuhan kebutuhan tersebut pada klinik. Selama proses yang berjalan, Klinik Karawaci Medika melakukan proses rawat jalan dengan kartu rekam medis pasien yang disimpan oleh pihak klinik yang berbentuk kertas sehingga kartu rekam medis pasien sulit untuk ditemukan ketika data rekam medis pasien dibutuhkan untuk pemeriksaan rawat jalan dan pada registrasi pasien rawat jalan, pasien diharuskan menunggu cukup lama karena masih manualnya proses pendaftaran pasien. Dari permasalahan tersebut didapatkan pemecahan masalah yaitu prototype aplikasi dapat mempermudah admin dalam menangani, mengelola data pasien dan mempermudah pasien dalam registrasi rawat jalan serta melihat rekam medis kapan dan dimana saja. Memudahkan pasien dalam rawat jalan karena tidak diperlu membawa kartu rawat jalan sehingga pasien maupun klink dapat sama sama terbantu dengan adanya rototype aplikasi rekam medis pasien berbasis web. Penelitian ini dibuat dengan menggunakan metode observasi, metode wawancara, analis SWOT dan studi pustaka. Menggunakan UML sebagai desain pemodelan.
\end{abstract}

Kata Kunci—Rekam Medis, Data Pasien, Teknologi Informasi, Pasien Rawat Jalan

\begin{abstract}
The application of technology in the health field can facilitate all the work of in particular the registration and processing of data which require speed, accuracy and kevalidan data. The patient's medical record application prototype web-based aim to do the fulfillment of those needs at the clinic. During the process of running the clinic, Karawaci Medika outpatient process with the patient's medical record cards are kept by the clinic that shaped paper patient medical record card so that it is difficult to be found when the patient's medical record data required for the inspection of outpatient and outpatient registration on, patients are required to wait for quite a long time because it is still the manual registration process of the patient. From that problem-solving is obtained i.e. prototype applications can make admin in dealing with patient data, manage and facilitate the registration of patients in outpatient as well as see medical record anytime and anywhere. Make it easier for patients in outpatient diperlu because it does not carry an outpatient card so that patients as well as klink could be same same rototype helped by the existence of the patient's medical record application is web-based. This research is created by using the method of observation, interview methods, SWOT analyst and studies of the literature. Using UML as modeling designs.
\end{abstract}

Keywords-medical record, Patient Data, information technology, Outpatient 


\section{PENDAHULUAN}

Penerapan Teknologi Informasi saat ini berkembang dengan pesat dan menyebar hampir di semua bidang. Tak terkecuali kegiatan manusia jaman sekarang kebutuhan terhadap informasi sangat penting sehingga informasi harus dapat diakses kapan saja dan dimana saja dengan berbasis online. Penerapan Teknologi Informasi ini dapat mempermudah dalam segala pekerjaan khususnya pendaftaran dan pengolahan data yang membutuhkan kecepatan, ketepatan dan kevalidan data.

Salah satu yang harusnya dapat merasakan dampak dalam mudahnya mengakses informasi yaitu pada bidang pelayanan kesehatan dimana pada saat ini Klinik Karawaci Medika memerlukan teknologi informasi yang digunakan untuk proses pendaftaran dan penyimpanan data pasien. Pada Klinik Karawaci Medika salah satu pelayanan yang disediakan yaitu pelayanan rawat jalan pasien. Karena dalam prosesnya pasien harus melewati beberapa tahapan seperti registrasi pasien rawat jalan, pemeriksaan pasien oleh dokter, resep dari dokter, pengambilan obat, pembayaran biaya rawat jalan dan obat yang dibutuhkan selama rawat jalan.

Selama proses yang berjalan, Klinik Karawaci Medika melakukan proses rawat jalan dengan kartu rekam medis pasien yang disimpan oleh pihak klinik yang berbentuk kertas sehingga kartu rekam medis pasien sulit untuk ditemukan ketika data rekam medis pasien dibutuhkan untuk pemeriksaan rawat jalan dan pada registrasi pasien rawat jalan, pasien diharuskan menunggu berjam-jam karena masih manualnya proses pendaftaran pasien. Oleh karena itu dibuatlah prototype aplikasi sistem rekam medis pasien berbasis web pada Klinik Karawaci Medika.

Adapun ruang lingkup dari sistem pelayanan pasien rawat jalan ini meliputi pengolahan data pasien, data kunjungan pasien, data riwayat kesehatan pasien, biaya pengobatan pasien dan data resep untuk pasien. Tujuan dibuatnya sistem ini adalah pelayanan pasien rawat jalan dapat dengan cepat terlayani kebutuhan kesehatannya Manfaat dari sisem yaitu pasien rawat jalan dapat melihat rekam medisnya melalui online dan memudahkan bagian admin klinik dalam pengolahan data pasien, biaya pengobatan dan mempermudah pemuatan rekapitulasi pasien rawat jalan yang dapat membantu dalam pengambilan keputusan oleh pihak klinik.

Dalam pembuatan penelitian ini perlu dilakukan studi pustaka untuk dijadikan sebagai referensi dari penelitian-penelitian yang sudah ada sebelumnya, diantaranya:

1. Penelitian yang dibuat oleh Maimunah, Dede Cahyadi dan Arsyad Septa Kuncoro yang berjudul "Test Online Pendukung Konsentrasi unggulan Artificial Informatics". Dalam penelitian tersebut menjelaskan tentang suatu sistem baru yaitu aplikasi ujian soal online khusus mahasiswa konsentrasi Artificial Informatics pada Perguruan Tinggi Raharja yang berbasis online[1].

2. Penelitian yang dibuat oleh Aris Martono, Padeli dan Dina Fitria Murad yang berjudul "Pengembangan Sistem Database Penempatan Tenaga Kerja Berbasis Web". Dalam penelitian tersebut bertujuan untuk tentang memudahkan pengguna mengakses secara mobile, penyedia lowongan kerja mempunyai banyak pilihan para pencari kerja, lembaga penyedia tenaga kerja yaitu perguruan tinggi akan mudah memantau informasi pasar kerja secara actual[2].

3. Penelitian yang dibuat oleh Ria Wulandari, Aditya Giyantono dan Agus Gunawan yang berjudul "Rancang Bangun Penggajian Karyawan Berbasis Web Pada PT Surganya Motor Indonesia ". Dalam penelitian tersebut bertujuan untuk mengurangi kesalahan dalam perhitungan gaji karyawan dan dapat menyingkat waktu dalam perhitungan gaji karyawan. Sehingga dapat mempermudah mekanisme untuk menyelesaikan suatu permasalahan bagi pihak yang terkait dalam penerapan sistem penggajian karyawan pada PT. Surganya Motor Indonesia[3].

4. Penelitian yang dibuat oleh Angelina Efrida Purba, Catur Putro Utomo dan Nurjamin yang berjudul "Sistem Kependudukan Desa Berbasis Web Pada Desa Cihuni Kecamatan Pagedangan Kabupaten Tangerang". Dalam penelitian tersebut bertujuan 
untuk membantu selain mengolah data kependudukan juga dapat menyimpan data-data dengan baik dan mempermudah masyarakat dalam hal kebutuhan pelayanan surat pengantar[4].

5. Penelitian yang dibuat oleh Ahmad Roihan dan Radifa Rahma Fitriani yang berjudul "Pemodelan Knowledge Management Servie Kendaran Berbasis Web Pada Bengkel Motor Sekolah Kejuruan". Dalam penelitian tersebut bertujuan untuk dapat menjadi solusi dari kebutuhan aliran pengetahuan (knowledge) yang tidak dihalangi oleh batasan waktu dan tempat[5].

6. Penelitian yang dibuat oleh Sutrisno dan Rohmawati Ningsih yang berjudul "Rancang Bangun Sistem Informasi Konsultasi Akademik Mahasiswa Jurusan Berbasis Web Pada STMIK Prastikom". Dalam penelitian tersebut bertujuan untuk dapat membantu pelayanan dosen menjadi maksimal, mahasiswa lebih termotivasi untuk menyelesaikan kuliahnya dan mengurangi tingkat kegagalan mahasiswa dalam menyelesaikan kuliahnya[6].

7. Penelitian yang dibuat oleh Abdul Hamid Arribathi, Wahyu Hidayat dan Rinaldy Qodar Saputra yang berjudul "Prototype Sistem Manajemen Kinerja Pegawai Negeri Kantor Urusan Agama Cibodas Kota Tangerang". Dalam penelitian tersebut bertujuan untuk dapat memudahkan pembuatan laporan kinerja pegawai negeri dan data tersimpan lebih terstruktur, efisien, dan efektif [7].

8. Penelitian yang dibuat oleh Suwarto, Dedy Prasetya Kristiadi dan Putri Rahayu yang berjudul "Pemodelan Knowledge Management Penguatan Karakter kerjasama SMK pada Industri Berbasis Web". Dalam penelitian tersebut bertujuan mengembangkan model knowledge management system dan merancang prototype dari model yang dikembangkan pada karakter kerja industry untuk dishare kepada para guru[8].

\section{METODE PENELITIAN}

Metode penelitiaan yang digunakan dalam pembuatan penelitian ini menggunakan metode pengumpulan data, konsep desain, dan analisa SWOT. Pengumpulan data yang dilakukan dalam penelitian ini menggunakan metode wawancara dan interview, data dan informasi yang diperoleh dari metode wawancara dan interview dilakukan melalui tanya jawab langsung dengan stakeholder yaitu Ibu Kiki selaku selaku humas yang bertanggung jawab pada kegiatan di klinik. Selanjutnya melakukan observasi dengan mendatangi langsung tempat penelitian di Klinik Karawaci Medika. Data dan hal-hal yang diperlukan dalam pembuatan web rekam medis pasien yang akan dibuat telah didapatkan dari metode observasi tersebut. Tahap berikutnya ialah melakukan studi literatur dengan mencari data-data yang diperlukan sebagai materi acuan dan referensi, data tersebut diperoleh dari jurnal-jurnal yang telah terbit sebelumnya dan yang telah dicantumkan ke dalam literature review. Selain literature review, pengumpulan data juga dilakukan dengan cara studi pustaka, data yang diperoleh melalui studi pustaka yaitu merupakan materi-materi yang digunakan sebagai bahan referensi dan acuan dari berbagai sumber.

Setelah metode pengumpulan data telah selesai dilakukan, selanjutnya yang akan dilakukan adalah tahap metode konsep desain menggunakan UML (Unified Modeling Language). Di bawah ini merupakan penjabaran dari metode desain menggunakan UML sistem yang berjalan: 
a. Use case sistem yang berjalan

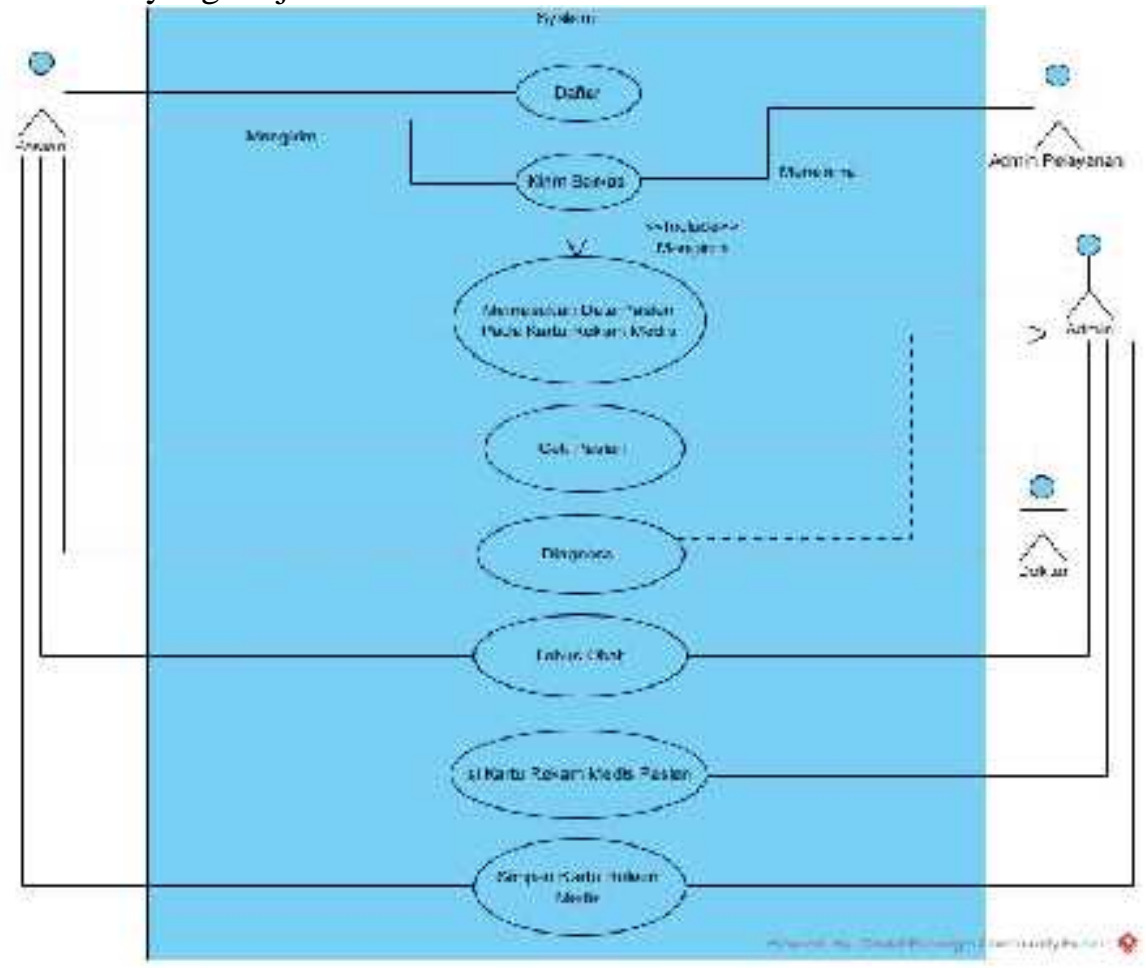

Gambar 1. Use case diagram sistem yang berjalan

Use case diagram pada Gambar 1 proses Proses Rekam Medis Klinik Karawaci Medika yang sedang berjalan saat ini, terdiri dari :

1. Terdapat 1 sistem mencakup proses kegiatan yang berjalan

2. Terdapat 4 actor dalam proses kegiatan yang berjalan, yaitu Pasien, admin pelayanan, admin dan dokter

3. 8 use case kegiatan oleh actor

b. Activity diagram pendaftaran rekam medis pasien

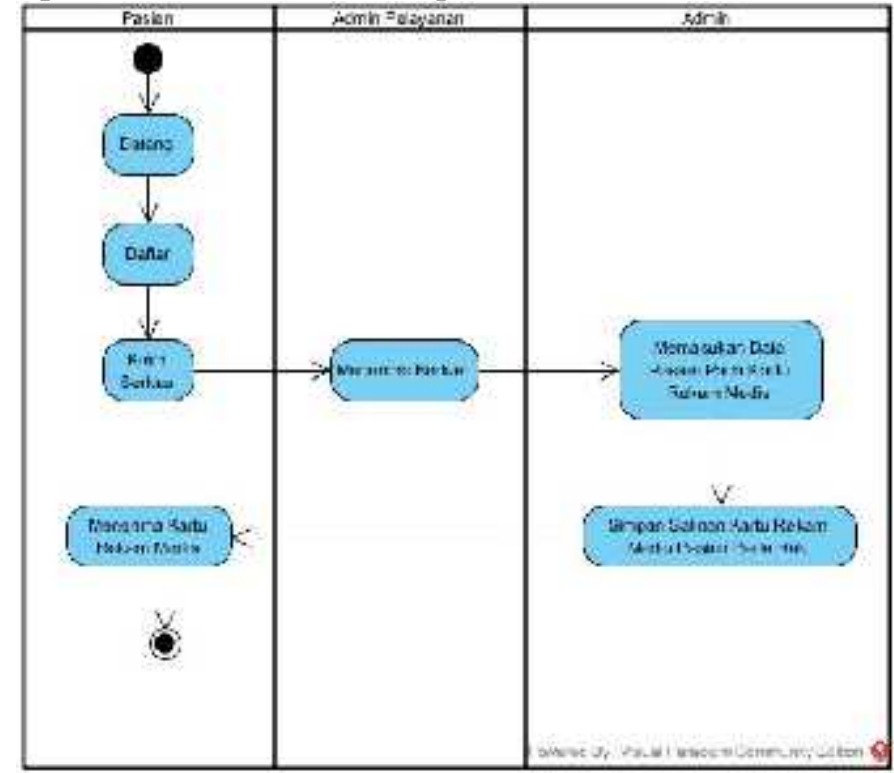

Gambar 2. Activity diagram sistem yang berjalan 
Activity diagram pada Gambar 2 proses pendaftaran rekam medis Klinik Karawaci Medika yang sedang berjalan saat ini, terdiri dari :

1. Terdapat 1 initial node

2. Terdapat 1 final node

3. Terdapat 3 swimline (pasien, admin dan admin pelayanan)

4. Terdapat 7 action yang menjelaskan alur cerita activity diagram

c. Activity diagram cek pasien

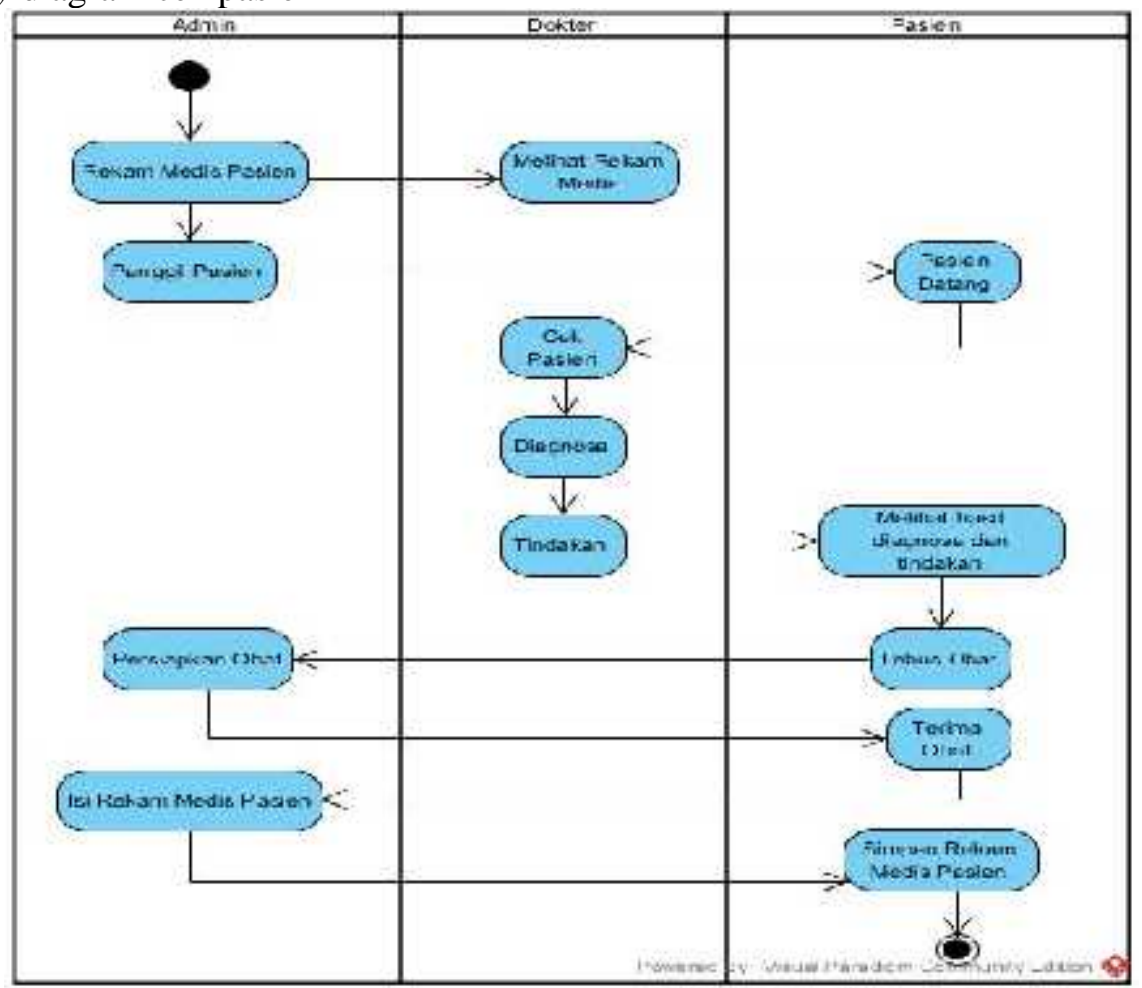

Gambar 3. Activity diagram sistem yang berjalan

Activity diagram pada Gambar 3 proses Proses Cek Pasien yang sedang berjalan saat ini, terdiri dari :

1. Terdapat 1 initial node

2. Terdapat 1 final node

3. Terdapat 3 swimline (admin, dokter dan pasien)

4. Terdapat 13 action yang menjelaskan alur cerita activity diagram

Selain metode pengumpulan data dan metode konsep desain, selanjutnya adalah melakukan metode analisa SWOT. Menurut Rangkuti (2013:14-15) mengemukakan bahwa analisis SWOT adalah indentifikasi berbagai faktor secara sistematis untuk merumuskan strategi perusahaan. Analisis ini didasarkan pada logika yang dapat memaksimalkan kekuatan (Strength) dan peluang (Opportunities), namun secara bersamaan dapat meminimalkan kelemahan (Weakness) dan ancaman (Threats). Proses pengambilan keputusan strategis selalu berkaitan dengan pengembangan misi, tujuan, strategi, dan kebijakan perusahaan. Dengan demikian, perencanaan strategis (strategic planner) harus menganalisis faktor-faktor strategi perusahaan (kekuatan, kelemahan, peluang, dan ancaman) dalam kondisi yang ada saat ini. Hal ini disebut dengan Analisis Situasi. Model yang paling populer untuk analisis situasi adalah Analisis SWOT[9]. 
Table 1. Analisa SWOT

\begin{tabular}{|c|c|c|}
\hline & Kekuatan (Strenght) & Kelemahan (Weakness) \\
\hline $\begin{array}{c}\text { MATRIX SWOT } \\
\text { Klinik Karawaci Medika }\end{array}$ & $\begin{array}{l}\text { 1. Tempat yang strategis } \\
\text { dalam menjangkau klinik } \\
\text { 2. Memilik ruang tunggu } \\
\text { yang besar } \\
\text { 3. Banyak pelayanan yang } \\
\text { disediakan oleh klinik }\end{array}$ & $\begin{array}{l}\text { 1. Menggunakan kartu dalam } \\
\text { rekam medisnya. } \\
\text { 2. Penyimpanan yang } \\
\text { menumpuk menjadi tidak } \\
\text { tertata dengan rapih }\end{array}$ \\
\hline Peluang (Opportunity) & Ancaman (Threat)) & \\
\hline $\begin{array}{l}\text { 1. Memberikan peluang } \\
\text { mahasiswa untuk } \\
\text { observasi dan wawancara } \\
\text { untuk mengembangkan } \\
\text { fasilitas klinik }\end{array}$ & $\begin{array}{ll}\text { 1. } & \text { Lembaga kesehatan } \\
\text { sejenis } \\
\text { 2. Kemajuan Teknologi } \\
\text { Komputer dan } \\
\text { Informatika }\end{array}$ & \\
\hline
\end{tabular}

\section{HASIL DAN PEMBAHASAN}

Setelah melaksanakan metode penelitian maka dibuatlah prototype aplikasi rekam medis pasien berbasis web yang akan digunakan untuk menunjang kegiatan proses rawat jalan pasien untuk mempercepat kinerja klinik. Prototype yang digunakan dalam pembuatan web rekam medis ini berupa ide-ide yang diambil menurut data yang didapat dari Klinik Karawaci Medika lalu akan dibuat menjadi media penghubung antara pasien dan admin Klinik Karawaci Medika, selain itu data-data yang tersimpan secara rapih dan berkala selama proses rawat jalan pada web klinik dapat memberikan evaluasi kesehatan terhadap pasien untuk lebih berhati-hati dalam menjaga kesehatannya sehingga pasien tidak perlu lagi membawa kartu rekam medis pasien dan manfaat lain untuk klinik yaitu memberikan pelayanan kesehatan yang mudah, murah dan nyaman. Di bawah ini merupakan penjabaran dari metode desain menggunakan UML sistem yang yang diusulkan dan prototype web Klinik Karawaci Medika:

a. Use case sistem yang diusulkan

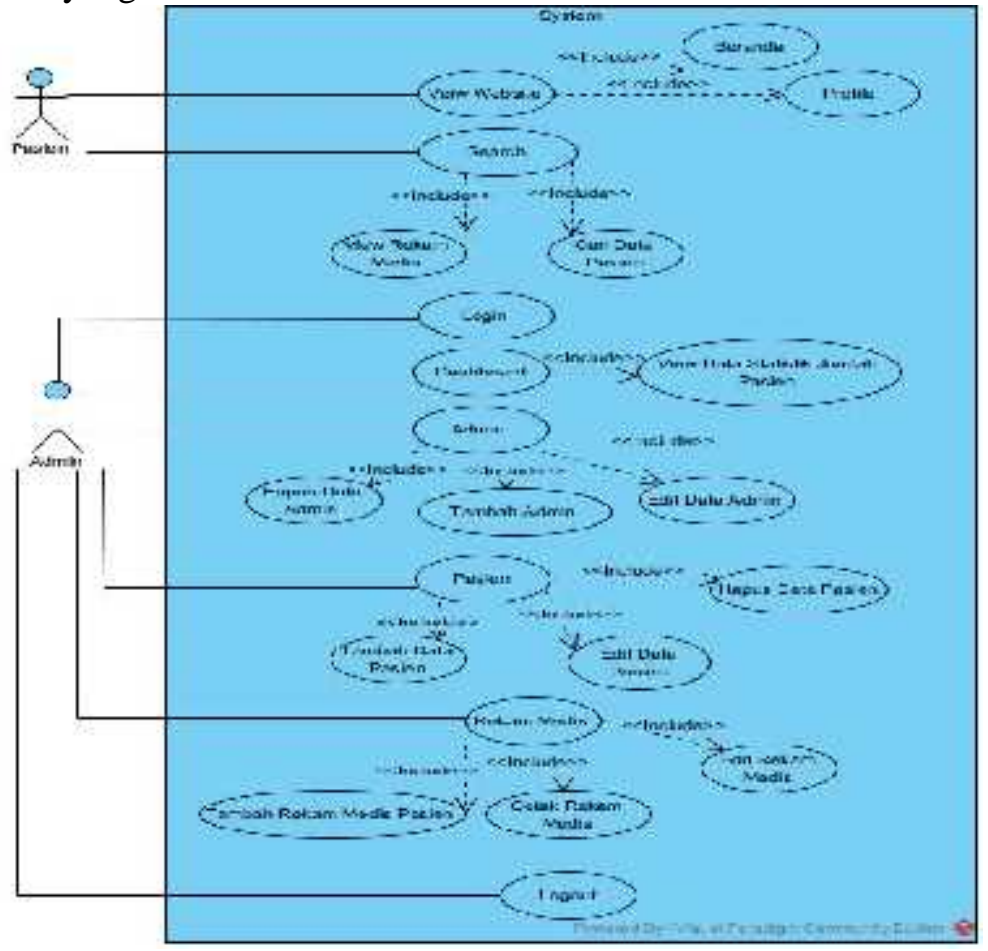

Gambar 4. Use case diagram sistem yang diusulkan 
Use case diagram pada Gambar 4 proses Proses Rekam Medis Klinik Karawaci Medika yang sedang diusulkan, terdiri dari :

1. Terdapat 1 sistem mencakup proses kegiatan yang berjalan

2. Terdapat 2 actor dalam proses kegiatan yang berjalan, yaitu Pasien dan admin

3. 22 use case kegiatan oleh actor

b. Class diagram sistem yang diusulkan
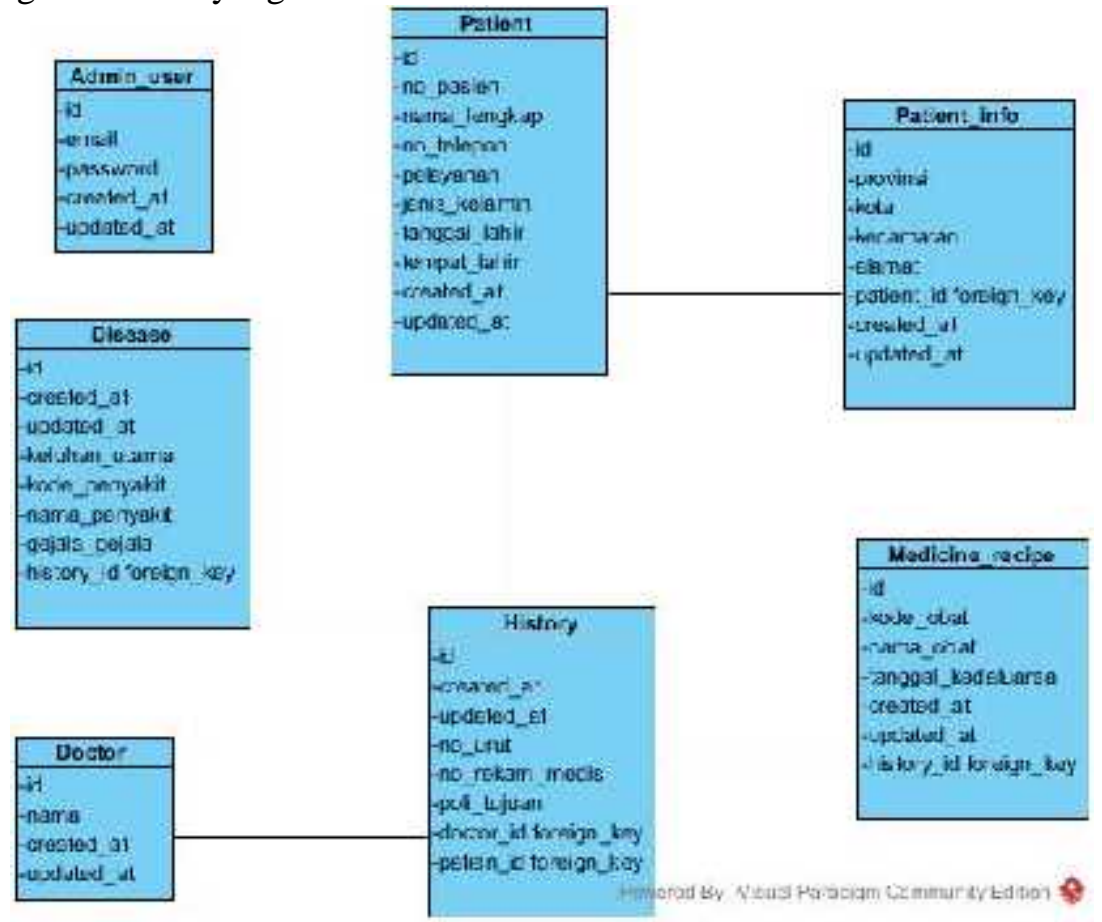

Gambar 5. class diagram sistem yang diusulkan

Dapat dijelaskan pada gambar 5 diatas adalah class diagram sistem klinik yang diusulkan, yaitu sebagai berikut:

1. Tabel patient, berisi atribut yang terdiri dari id, no_pasien, nama_lengkap, no_telepon, pelayanan, jenis_kelamin, tanggal_lahir, tempat_lahir created_at dan updated_at

2. Tabel admin, berisi atribut id, email, password, created_at dan updated_at

3. Tabel disease, berisi atribut id, keluhan_utama, kode, nama_penyakit, gejala_gejala, history_id_foriegn_key, created_at dan updated_at

4. Tabel doctor, berisi atribut id, nama, created_at dan updated_at

5. Tabel history, berisi atribut yang terdiri dari id, no_urut, no_rekam_medis, poli_tujuan, doctor_id_foreign_key, patient_id_foreign_key, created_at dan updated_at

6. Tabel Patient_info, berisi atribut yang terdiri dari id, provinsi, kota, kecamatan, alamat, patient_id_foreign_key, created_at dan updated_at

7. Tabel medicine_recipe, berisi atribut yang terdiri dari id, kode_obat, nama_obat, tanggal_kadaluarsa, created_at dan updated_at

c. Rancangan prototype aplikasi

1. Menu login admin 


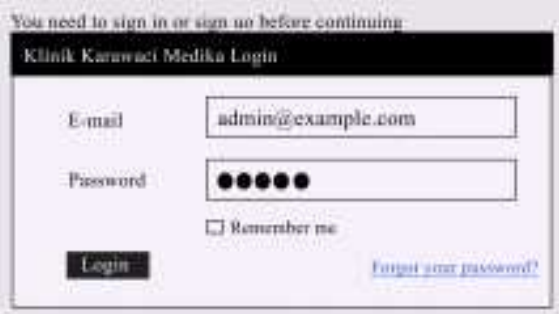

Gambar 6 menu login admin

Dapat dijelaskan pada gambar 6 diatas adalah menu login admin, dimana hak akses klinik dibatasi hanya pengguna yang diperbolehkan/terdaftar yang memiliki wewenang terhadap web klinik.

2. Menu tambah pasien admin

Klinik Karawaci Medika Dasbboard Admin Pesich Rekam Medis admingexample.com Log out
Ansistiniar

\section{Pasien Baru}

Pelayanan
No. Kartu BPJS
Jenis Peserta
No. Unut
No. Rekam
Tanggal Daftar
Nama Leagkap
Jenis Kelamin
Tempot Lahir
Tempat Tinggal:
Proviasi
Kota/Kabupaten
Kecamatan
Alanat
No. Telepon

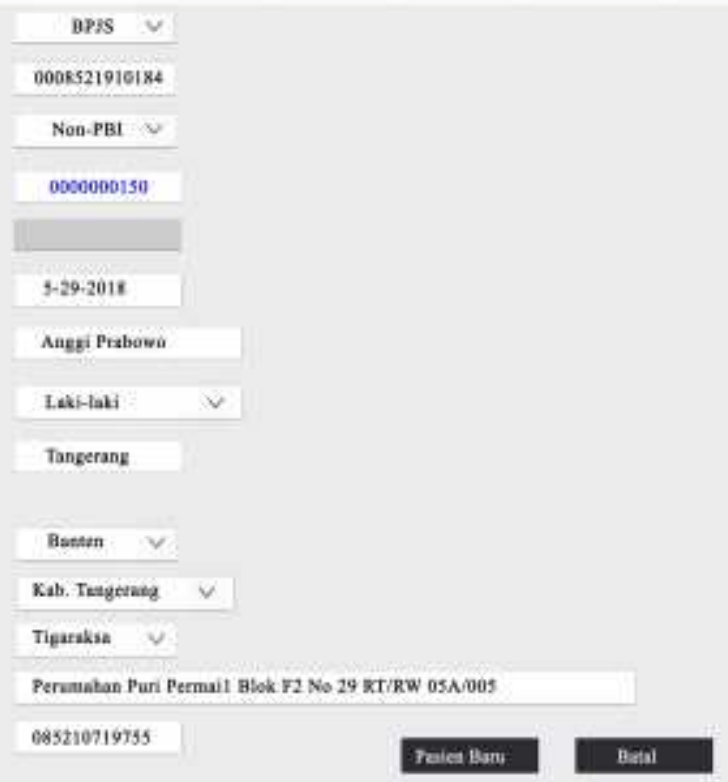

Gambar 7 menu tambah pasien

Dapat dijelaskan pada gambar 7 diatas adalah menu tambah pasien admin, admin yang memiliki hak akses dapat menambahkan pasien baru ke web klinik untuk disimpan sebagai pasien klinik. 
3. Menu isi rekam medis pasien admin

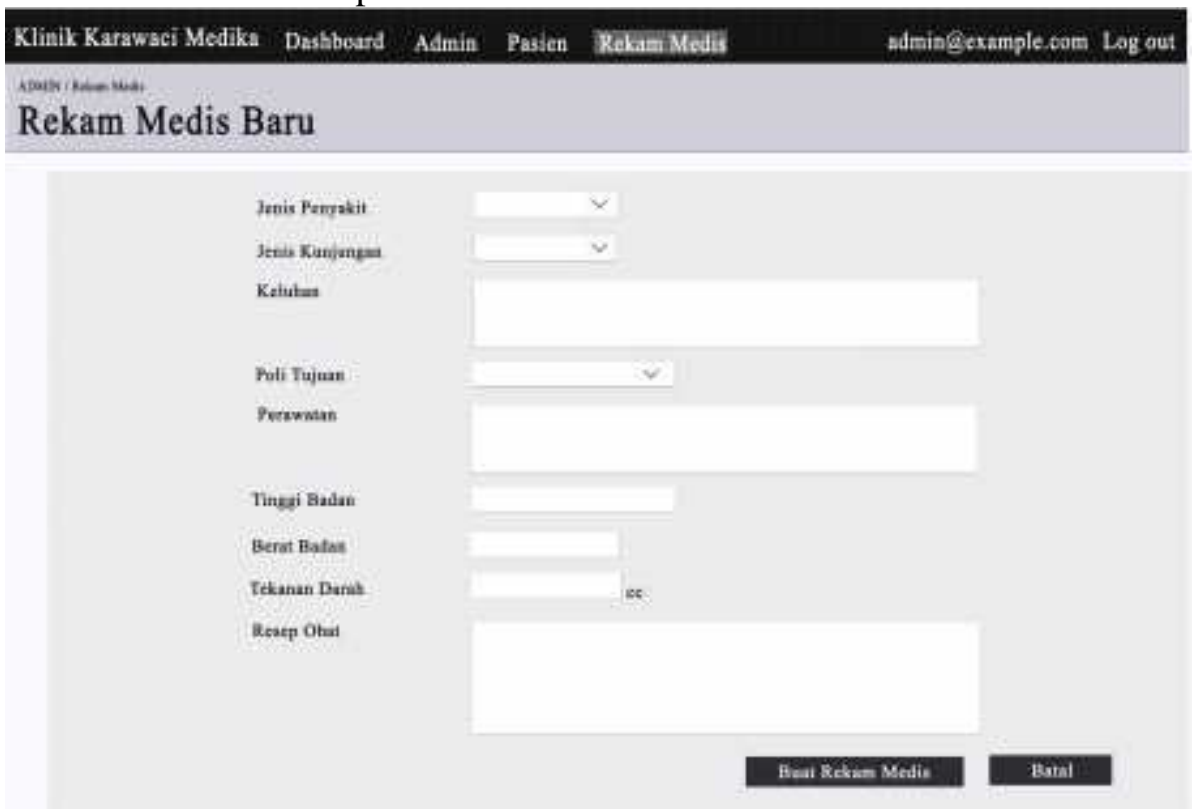

Gambar 8. Menu isi rekam medis pasien admin

Dapat dijelaskan pada gambar 8 diatas adalah menu isi rekam medis pasien admin, admin yang sudah menambahkan pasien dapat mengisi rekam medis pasien yang sudah diperiksa oleh dokter sebelumnya.

4. Tampilan menu home pasien

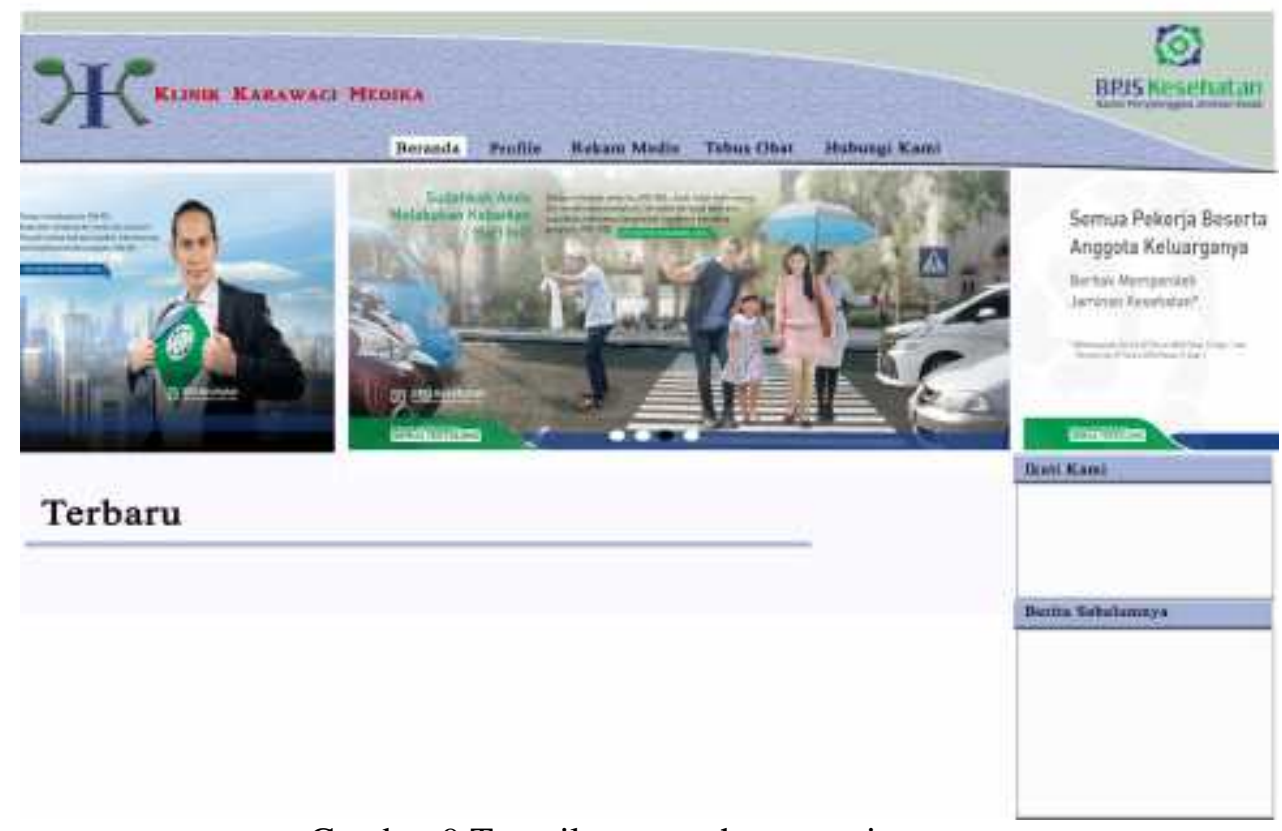

Gambar 9 Tampilan menu home pasien

Dapat dijelaskan pada gambar 9 diatas adalah tampilan menu home pasien, dimana pasien yang sudah terdaftar oleh admin klinik dapat mengunjungi web klinik yang ada. 
5. Tampilan menu profile pasien

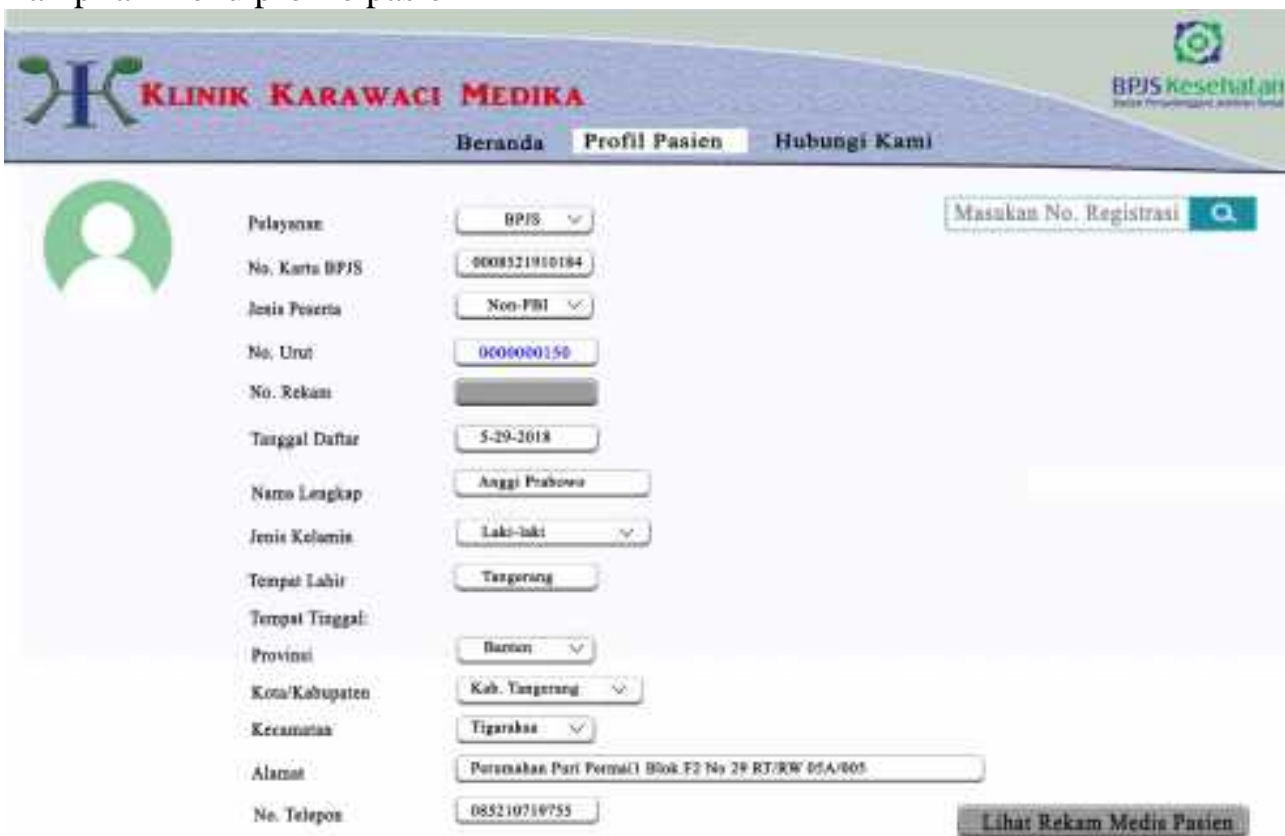

Gambar 10. Tampilan menu profile pasien

Dapat dijelaskan pada gambar 10 diatas adalah tampilan menu profile pasien, dimana pasien yang sudah terdaftar dapat ke menu profile pasien dengan memasukan no. registrasi pasien yang diberikan oleh klinik. Pasien dapat melihat profile dan rekam medis pasiennya lewat handphone dan laptop dengan media internet kapan dan dimana saja.

6. Tampilan menu rekam medis pasien

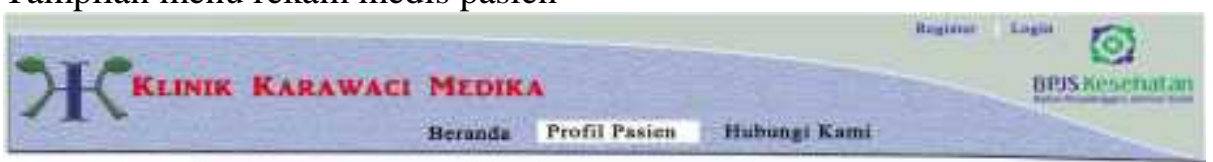

Lihus Rekam Mediu Paien

\begin{tabular}{|c|c|c|c|c|c|c|c|c|}
\hline Jua Finyant & 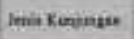 & Katahia. & Men Tüuan: & Penmint & Theat Dutel. & Now Batan & Taksas Darth & Anesp Otat \\
\hline & $\square$ & & & 4 & 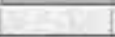 & 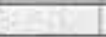 & 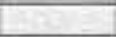 & 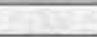 \\
\hline & 5 & & & & & & & \\
\hline$=$ & EE & & & & & & 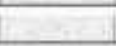 & \\
\hline & & & & & 25 & 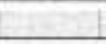 & & \\
\hline & 10 & & & & & & & \\
\hline
\end{tabular}

Pasien Baru \& Belum Memiliki Rekam Medis

Gambar 11 Tampilan menu rekam medis pasien

Dapat dijelaskan pada gambar 11 diatas adalah tampilan menu rekam medis pasien, setelah pasien memasukan no. registrasinya lalu menampilkan profile pasien dibawahnya ada tombol button dimana akan muncul tampilan seperti yang diatas 


\section{KESIMPULAN}

Berdasarkan kesimpulan dari topik pembahasan Prototype Aplikasi Berbasis Web Pada Klinik Karawaci Medika yaitu sebagai berikut:

1. Prototype aplikasi berbasis web pada klinik ini menjadikan pasien rawat jalan hanya perlu menyebutkan no registrasi pada admin klinik tanpa harus membawa bawa kartu rawat jalan.

2. Dengan adanya prototype aplikasi berbasis web pada klinik ini pasien rawat jalan bisa ditangani dengan mudah oleh admin dalam mengelola data pasien rawat jalan

3. Menghasilkan sistem yang dapat mempermudah dalam mengelola data pasien dan rekam medis pasien yang berfungsi mempermudah pasien saat kembali berkunjung dengan menggunakan sistem pada computer admin.

4. Prototype aplikasi berbasis web pada klinik yang diajukan ini memberi suatu alternatif pemecahan masalah dalam sistem registrasi dan pengambilan nomor untuk pasien

\section{SARAN}

Adapun saran-saran yang dapat digunakan untuk pengembangan perangkat lunak yang sudah dibuat sebagai berikut:

1. Menambahkan fitur pembayaran via debit.

2. Menambahkan fitur rawat inap

\section{UCAPAN TERIMA KASIH}

Terima Kasih kepada rekan-rekan STMIK Raharja yang telah mendukung dalam penelitian ini dan memberikan masukan-masukan yang positif.

\section{DAFTAR PUSTAKA}

[1] Maimunah, Dede Cahyadi dan Arsyad Septa Kuncoro, 2015, Test Online Pendukung Konsentrasi unggulan Artificial Informatics, Vol. 1 No. 1, Jurnal CERITA, STMIK Raharja, Tangerang.

[2] Martono, Aris, Padeli dan Dina Fitria Murad, 2009, Pengembangan Sistem Database Penempatan Tenaga Kerja Berbasis Web, Vol. 2 No. 3, Jurnal CERITA, STMIK Raharja, Tangerang.

[3] Wulandari, Ria, Aditya Giyantono dan Agus Gunawan, 2017, Rancang Bangun Penggajian Karyawan Berbasis Web Pada PT Surganya Motor Indonesia, Vol. 3 No. 1, Jurnal CERITA, STMIK Raharja, Tangerang.

[4] Purba, Angelina Efrida Purba, Catur Putro Utomo dan Nurjamin, 2017, Sistem Kependudukan Desa Berbasis Web Pada Desa Cihuni Kecamatan Pagedangan Kabupaten Tangerang, Vol. 3 No. 2, Jurnal CERITA, STMIK Raharja, Tangerang.

[5] Roihan, Ahmad dan Radifa Rahma Fitriani, 2018, Pemodelan Knowledge Management Servie Kendaran Berbasis Web Pada Bengkel Motor Sekolah Kejuruan, Vol. 4 No. 2, Jurnal CERITA, STMIK Raharja, Tangerang.

[6] Sutrisno dan Rohmawati Ningsih, 2018, Rancang Bangun Sistem Informasi Konsultasi Akademik Mahasiswa Jurusan Berbasis Web Pada STMIK Prastikom, Vol. 4 No. 2, Jurnal CERITA, STMIK Raharja, Tangerang.

[7] Arribathi, Abdul Hamid Arribathi, Wahyu Hidayat dan Rinaldy Qodar Saputra, 2018, Prototype Sistem Manajemen Kinerja Pegawai Negeri Kantor Urusan Agama Cibodas Kota Tangerang, Vol. 4 No. 2, Jurnal CERITA, STMIK Raharja, Tangerang.

[8] Suwarto, Dedy Prasetya Kristiadi dan Putri Rahayu, 2018, Pemodelan Knowledge Management Penguatan Karakter kerjasama SMK pada Industri Berbasis Web, Vol. 4 No. 2, Jurnal CERITA, STMIK Raharja, Tangerang. 
[9] Rangkuti, Freddy. 2013. Teknik Membedah Kasus Bisnis Analisis SWOT Cara Perhitungan Bobot, Rating, dan OCAI. Penerbit PT. Gramedia Pustaka Utama. Jakarta. 